\title{
Observations on the estimation of the quantity of emphysema in the lungs by the point- sampling method
}

\author{
JOHNA. ANDERSONANDA.S. DUNNILL \\ From the Unit of Biometry, University of Oxford, and the Department of Pathology, The Radcliffe \\ Infirmary, Oxford
}

Assessment of the amount of emphysema in the lungs at necropsy necessitates measurement of the volumes of abnormal and normal tissue present. In a previous paper (Dunnill, 1962) a method was described for estimating separately the volumes of the emphysematous parenchyma, the normal parenchyma, and of the conducting vessels and airways (that is, the non-parenchyma) by a simple point-counting technique. This method entails fixing the lung in a controlled state of inflation and then cutting the fixed lung into approximately $1-\mathrm{cm}$. thick slices. The pointcounting grid, composed of points drawn on a transparent plastic material, is placed over each slice, and the position of each point is noted, i.e., whether it lies over normal lung parenchyma, emphysematous parenchyma, or non-parenchyma. The total number of points lying on each component is proportional to the area of each component on the cut slice, which in turn, according to the theorem of Delesse (1847), is proportional to the volume of the component in the lung.

In the original paper the points were placed $1 \mathrm{~cm}$. apart, at the angles of equilateral triangles, and this entailed counting some 2,000 to 3,000 points for each lung. If large numbers of lungs are to be assessed quantitatively in this manner, it is desirable to know (a) how many points it is necessary to count to achieve any given degree of accuracy; and $(b)$ whether it is necessary to examine every slice of the lung in order to obtain an accurate measurement of the quantity of emphysema in that lung.

It would be an obvious advantage if, for instance, the quantity of emphysema in a lung could be estimated from examination, by point counting, of a single slice of lung, or of a section of whole lung prepared by the Gough and Wentworth (1949) technique. It is the purpose of this paper to investigate these two questions.

\section{MATERIAL AND METHODS}

The lungs from five cases of emphysema were examined. In cases I and II the emphysema was mainly of the centrilobular type, whereas in cases III, IV, and V it was mainly of the panacinar destructive type. All the lungs were fixed by the formalinsteam method of Weibel and Vidone (1961). The fixed lungs were then cut into slices measuring approximately $1 \mathrm{~cm}$. in thickness, and the slices were laid out side by side on a table in a good light.

GRIDS All the grids used in this investigation consisted of points placed at the angles of equilateral triangles (see Dunnill (1962) Fig. 2). The points were marked on a transparent plastic material, with the trade name Nearglass, using a waterproof India ink. Three types of grid were used: (1) grid A, with the points placed $0.65 \mathrm{~cm}$. apart; (2) grid $B$, with the points placed $1.30 \mathrm{~cm}$. apart ; and (3) grid C, with the points placed $2.60 \mathrm{~cm}$. apart.

In case I all the slices were tested with all the grids in order to assess the degree of accuracy obtainable with the points placed at various distances apart.

All the slices in cases I, II, III, IV, and V were tested with grid B in order to test whether there was a significant difference between the slices.

TECHNIQUE OF POINT COUNTING The components assessed on each slice were: (a) the non-parenchyma, that is, the conducting tissues and blood vessels down to $0.1 \mathrm{~cm}$. diameter, $(b)$ the normal lung parenchyma, and $(c)$ the emphysematous parenchyma.

The grid in use was placed over each slice in turn, and the position of each point lying on the slice was assessed. If the point lay directly over one of the components listed above, it was recorded as being in that component. Difficulty arises where a point appears to lie on the boundary between the components. In this situation a convention is adopted, similar to that used in performing cell counts in haematology, that the tissue above and to the left of the point is considered as the component in which the 
point lies. The position of each point is recorded with a digital differential counter of the type used in haematology laboratories.

\section{RESULTS AND DISCUSSION}

Table I shows the results in case $I$, where all the slices were sampled by each of the three grids. It can be seen that with grid $A$, where the points were $0.65 \mathrm{~cm}$. apart, 3,063 points were counted, whereas with grid $C$, where the points were 2.60 cm. apart, only 196 points were counted. The time difference in using the three grids was considerable. Grid A took over an hour to use, whereas grid B took only 15 minutes, and grid C about 7 minutes. Obviously grid $\mathbf{A}$ is much more accurate than grid $B$ or grid C, but the important question is how much greater is the error if grid B or grid $\mathbf{C}$ is used.

Calculation of the exact standard error is very difficult in this set of circumstances, since the points used are not randomly distributed, though the grids themselves are placed at random on the slices. However, if the standard error is estimated, assuming the points to be randomly distributed, then this will give an upper bound of the standard error, i.e., the actual standard error will be less than the figure calculated. Accordingly, a standard error, $r$, has been calculated for each component on each slice using the expression

$$
r=\sqrt{\frac{A(100-A)}{N}}
$$

where $A$ is the percentage of points lying in a given component and $N$ is the total number of points counted on each slice.

In Table I the standard error is given for each component on each slice. A standard error for the whole lung is also given, compounded from the standard errors for each slice, for each of the three grids. The compounded standard error, $s$, is given by

$$
s=\sqrt{\sum_{i} N_{i} A_{i}\left(100-A_{i}\right)}
$$

where the summation extends over all slices. $\boldsymbol{A}_{\boldsymbol{i}}$

TABLE I

\begin{tabular}{|c|c|c|c|c|c|c|c|c|}
\hline & & \multicolumn{2}{|c|}{ Non-parenchyma } & \multicolumn{2}{|c|}{ Normal Parenchyma } & \multicolumn{2}{|c|}{ Emphysematous Parenchyma } & \multirow{2}{*}{$\begin{array}{l}\text { Total No. } \\
\text { of Points }\end{array}$} \\
\hline \multicolumn{2}{|c|}{ Slice No. } & $\begin{array}{l}\text { Percentage } \\
\text { Volume }\end{array}$ & $\begin{array}{l}\text { Standard } \\
\text { Error }\end{array}$ & $\begin{array}{l}\text { Percentage } \\
\text { Volume }\end{array}$ & $\begin{array}{c}\text { Standard } \\
\text { Error }\end{array}$ & $\begin{array}{l}\text { Percentage } \\
\text { Volume }\end{array}$ & $\underset{\text { Error }}{\text { Standard }}$ & \\
\hline $\mathbf{I}$ & $\begin{array}{l}\mathbf{A} \\
\mathbf{B} \\
\mathbf{C}\end{array}$ & $\begin{array}{r}16 \cdot 1 \\
1 \cdot 8 \\
5 \cdot 8\end{array}$ & $\begin{array}{l}2.65 \\
1.76 \\
5.67\end{array}$ & $\begin{array}{l}65 \cdot 8 \\
70 \cdot 2 \\
64 \cdot 8\end{array}$ & $\begin{array}{r}3.41 \\
6.06 \\
11 \cdot 57\end{array}$ & $\begin{array}{l}18 \cdot 1 \\
28 \cdot 0 \\
29 \cdot 4\end{array}$ & $\begin{array}{r}2.77 \\
5.95 \\
11.05\end{array}$ & $\begin{array}{r}193 \\
57 \\
17\end{array}$ \\
\hline II & $\begin{array}{l}\mathbf{A} \\
\mathbf{B} \\
\mathbf{C}\end{array}$ & $\begin{array}{l}14 \cdot 4 \\
12 \cdot 7 \\
16 \cdot 7\end{array}$ & $\begin{array}{l}2 \cdot 25 \\
4 \cdot 20 \\
8 \cdot 79\end{array}$ & $\begin{array}{l}58 \cdot 4 \\
63 \cdot 5 \\
55 \cdot 6\end{array}$ & $\begin{array}{r}3 \cdot 16 \\
6 \cdot 07 \\
11 \cdot 70\end{array}$ & $\begin{array}{l}22 \cdot 7 \\
23 \cdot 8 \\
27 \cdot 7\end{array}$ & $\begin{array}{r}2.69 \\
5 \cdot 28 \\
10.55\end{array}$ & $\begin{array}{r}243 \\
63 \\
18\end{array}$ \\
\hline III & $\begin{array}{l}\mathbf{A} \\
\mathbf{B} \\
\mathbf{C}\end{array}$ & $\begin{array}{r}18 \cdot 7 \\
16 \cdot 2 \\
4 \cdot 8\end{array}$ & $\begin{array}{l}2 \cdot 14 \\
4 \cdot 28 \\
4 \cdot 65\end{array}$ & $\begin{array}{l}46 \cdot 7 \\
50 \cdot 0 \\
57 \cdot 1\end{array}$ & $\begin{array}{r}2 \cdot 74 \\
5 \cdot 81 \\
10 \cdot 80\end{array}$ & $\begin{array}{l}34 \cdot 6 \\
33 \cdot 8 \\
38 \cdot 1\end{array}$ & $\begin{array}{r}2.61 \\
5 \cdot 50 \\
10.60\end{array}$ & $\begin{array}{r}332 \\
74 \\
21\end{array}$ \\
\hline IV & $\begin{array}{l}\mathbf{A} \\
\mathbf{B} \\
\mathbf{C}\end{array}$ & $\begin{array}{l}21.4 \\
30.9 \\
31.8\end{array}$ & $\begin{array}{l}2 \cdot 11 \\
4 \cdot 69 \\
9 \cdot 93\end{array}$ & $\begin{array}{l}51 \cdot 4 \\
47 \cdot 4 \\
36 \cdot 4\end{array}$ & $\begin{array}{r}2 \cdot 57 \\
5 \cdot 07 \\
10 \cdot 25\end{array}$ & $\begin{array}{l}27 \cdot 2 \\
21 \cdot 7 \\
31 \cdot 8\end{array}$ & $\begin{array}{l}2 \cdot 28 \\
4 \cdot 18 \\
9 \cdot 93\end{array}$ & $\begin{array}{r}379 \\
97 \\
22\end{array}$ \\
\hline $\mathbf{V}$ & $\begin{array}{l}\mathbf{A} \\
\mathbf{B} \\
\mathbf{C}\end{array}$ & $\begin{array}{l}23 \cdot 5 \\
27 \cdot 0 \\
26 \cdot 0\end{array}$ & $\begin{array}{l}1 \cdot 98 \\
4 \cdot 21 \\
8 \cdot 44\end{array}$ & $\begin{array}{l}43 \cdot 1 \\
44 \cdot 2 \\
44 \cdot 4\end{array}$ & $\begin{array}{l}2 \cdot 33 \\
4 \cdot 71 \\
9 \cdot 56\end{array}$ & $\begin{array}{l}33.4 \\
28 \cdot 8 \\
29 \cdot 6\end{array}$ & $\begin{array}{l}2 \cdot 22 \\
4 \cdot 30 \\
8 \cdot 78\end{array}$ & $\begin{array}{r}452 \\
111 \\
27\end{array}$ \\
\hline VI & $\begin{array}{l}\mathbf{A} \\
\mathbf{B} \\
\mathbf{C}\end{array}$ & $\begin{array}{l}26 \cdot 5 \\
26 \cdot 7 \\
22 \cdot 2\end{array}$ & $\begin{array}{l}2 \cdot 19 \\
4 \cdot 32 \\
8 \cdot 00\end{array}$ & $\begin{array}{l}41 \cdot 3 \\
40 \cdot 0 \\
29 \cdot 6\end{array}$ & $\begin{array}{l}2 \cdot 44 \\
4 \cdot 78 \\
8 \cdot 78\end{array}$ & $\begin{array}{l}32 \cdot 2 \\
33 \cdot 3 \\
48 \cdot 2\end{array}$ & $\begin{array}{l}2 \cdot 32 \\
4 \cdot 60 \\
9 \cdot 61\end{array}$ & $\begin{array}{r}407 \\
105 \\
27\end{array}$ \\
\hline VII & $\begin{array}{l}\mathbf{A} \\
\mathbf{B} \\
\mathbf{C}\end{array}$ & $\begin{array}{l}11 \cdot 4 \\
12 \cdot 4 \\
12 \cdot 5\end{array}$ & $\begin{array}{l}1 \cdot 57 \\
3 \cdot 35 \\
6 \cdot 75\end{array}$ & $\begin{array}{l}43 \cdot 3 \\
42 \cdot 7 \\
41 \cdot 7\end{array}$ & $\begin{array}{r}2.44 \\
5.24 \\
10.07\end{array}$ & $\begin{array}{l}45 \cdot 3 \\
44 \cdot 9 \\
45 \cdot 8\end{array}$ & $\begin{array}{r}2 \cdot 45 \\
5 \cdot 27 \\
10 \cdot 17\end{array}$ & $\begin{array}{r}413 \\
89 \\
24\end{array}$ \\
\hline VIII & $\begin{array}{l}\mathbf{A} \\
\mathbf{R} \\
\mathbf{C}\end{array}$ & $\begin{array}{l}6 \cdot 1 \\
3 \cdot 6 \\
4 \cdot 5\end{array}$ & $\begin{array}{l}1 \cdot 32 \\
2 \cdot 04 \\
4 \cdot 42\end{array}$ & $\begin{array}{l}46 \cdot 5 \\
48 \cdot 2 \\
45 \cdot 5\end{array}$ & $\begin{array}{r}2.74 \\
5.48 \\
10.62\end{array}$ & $\begin{array}{l}47 \cdot 4 \\
48 \cdot 2 \\
50 \cdot 0\end{array}$ & $\begin{array}{r}2 \cdot 74 \\
5 \cdot 48 \\
10 \cdot 64\end{array}$ & $\begin{array}{r}331 \\
83 \\
22\end{array}$ \\
\hline IX & $\begin{array}{l}\mathbf{A} \\
\mathbf{B} \\
\mathbf{C}\end{array}$ & $\begin{array}{l}9.9 \\
7.6 \\
5.6\end{array}$ & $\begin{array}{l}1.69 \\
3.00 \\
5.47\end{array}$ & $\begin{array}{l}47 \cdot 3 \\
46 \cdot 2 \\
61 \cdot 1\end{array}$ & $\begin{array}{r}2.82 \\
5.65 \\
11.49\end{array}$ & $\begin{array}{l}42 \cdot 8 \\
46 \cdot 2 \\
33 \cdot 3\end{array}$ & $\begin{array}{r}2.80 \\
5.65 \\
11 \cdot 11\end{array}$ & $\begin{array}{r}313 \\
78 \\
18\end{array}$ \\
\hline Mean & $\begin{array}{l}\mathbf{A} \\
\mathbf{B} \\
\mathbf{C}\end{array}$ & $\begin{array}{l}17 \cdot 0 \\
17 \cdot 0 \\
15 \cdot 3\end{array}$ & $\begin{array}{l}0.67 \\
1.32 \\
2.48\end{array}$ & $\begin{array}{l}47.8 \\
48.6 \\
46.9\end{array}$ & $\begin{array}{l}0.89 \\
1.79 \\
3.47\end{array}$ & $\begin{array}{l}35 \cdot 2 \\
34 \cdot 4 \\
37 \cdot 8\end{array}$ & $\begin{array}{l}0.85 \\
1.69 \\
3.41\end{array}$ & $\begin{array}{r}3,063 \\
757 \\
196\end{array}$ \\
\hline
\end{tabular}

ANALYSIS OF ALL SLICFS IN CASE I USING GRIDS A, B, AND C 


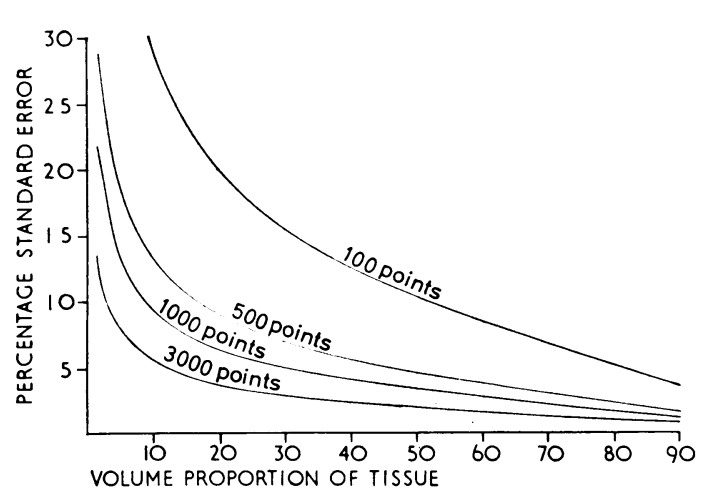

FIG. 1. A series of graphs showing the relationship between the total number of points sampled, the percentage volume of tissue estimated, and the percentage standard error of the estimate.

is the percentage of points lying in a given component, and $N_{i}$ is the total number of points counted on the $i$ th slice. The difference between this estimate of the standard error and the one obtained by substituting the overall percentages into the expression for $r$ was quite small, so that the graphical representations in Figure 1, necessarily based on this latter estimate, are a good guide to the number of points required to reach a given degree of accuracy.

It will be seen that, although the standard error for the final values of the whole lung of each of the three components is four times as great for grid $\mathrm{C}$ as for grid $\mathbf{A}$, it is still relatively small. Thus with grid $\mathrm{A}$, the percentage of emphysematous lung is given as $35 \cdot 2 \pm 0.85$, whereas with grid $C$ it is given as $37 \cdot 8 \pm 3 \cdot 41$. This is a percentage standard error of approximately $9 \%$ in the estimation of the degree of emphysema with grid C. This may be acceptable for most practical purposes, but if an error of approximately $5 \%$ is required, then obviously grid $B$ is the one to use. Using grid B, the estimate of the volume of emphysematous tissue was $34.4 \pm 1 \cdot 69 \%$. This would seem to give a suitable compromise between accuracy and time. The smaller the proportion to be estimated, the larger is the number of points that must be counted for any given standard error. Furthermore, since the error depends on the square root of the number of observations, if it is desired to halve the standard error it is necessary to count four times the number of points. In Fig. 1 a series of graphs has been drawn to illustrate the percentage standard error of different proportions of tissue obtained with grids of varying sizes. The percentage standard error was calculated from the expression

$$
\frac{\text { standard error of } p}{p} \cdot 100
$$

where $p$ is the percentage proportion of the component under consideration. Thus from the figure it can be seen that if the component which it is desired to estimate occupies $15 \%$ by volume of the lung, it is necessary to use a grid which, when placed on all the slices of the lung, will give a total point count of 3,000 to achieve a percentage standard error of $5 \%$. On the other hand, if the component occupies $45 \%$ of the lung, the same degree of accuracy can be obtained by counting 500 points in the lung. If as much as $80 \%$ of the lung is occupied by the component, then a count of 100 points will suffice to give a standard error of $5 \%$.

The second part of this investigation is concerned with whether or not an acceptable estimate of the quantity of emphysema in a whole lung can be obtained from examination of a single slice of that lung. All the slices in each lung were examined with grid $\mathrm{B}$. The question at issue when sampling the lungs to estimate the proportion of the components, non-parenchyma, normal parenchyma, and emphysematous parenchyma, is whether the components are distributed homogeneously throughout the lung or not. If they are, the sets of proportions obtained by taking slices from different parts of the lung would be expected to be approximately the same for each slice, allowing for a small sampling error. If a random sample of points is taken from each slice, and these points are allocated to the three components, then a table can be drawn up as shown in Table II. It is

T A B LE II

MODEL TABLE FOR HOMOGENEITY TEST BETWEEN LUNG SLICES

\begin{tabular}{|c|c|c|c|c|c|c|c|}
\hline \multirow{2}{*}{$\begin{array}{l}\text { Slice } \\
\text { No. }\end{array}$} & \multicolumn{2}{|c|}{$\begin{array}{c}\text { Non- } \\
\text { parenchyma }\end{array}$} & \multicolumn{2}{|c|}{$\begin{array}{c}\text { Normal } \\
\text { Parenchyma }\end{array}$} & \multicolumn{2}{|c|}{$\begin{array}{c}\text { Emphy- } \\
\text { sematous } \\
\text { Parenchyma }\end{array}$} & \multirow{2}{*}{$\begin{array}{c}\text { Total } \\
\text { No. } \\
\text { of } \\
\text { Points }\end{array}$} \\
\hline & $\begin{array}{l}\text { No. of } \\
\text { Points }\end{array}$ & $\%$ & $\begin{array}{l}\text { No. of } \\
\text { Points }\end{array}$ & $\%$ & $\begin{array}{l}\text { No. of } \\
\text { Points }\end{array}$ & $\%$ & \\
\hline 1 & $a_{1}$ & $\mathrm{p}_{1}$ & $\mathrm{~b}_{1}$ & $\mathrm{q}_{1}$ & $c_{1}$ & $t_{1}$ & $\mathrm{n}_{1}$ \\
\hline 2 & $a_{2}$ & $\mathrm{p}_{2}$ & $\mathrm{~b}_{2}$ & $q_{2}$ & $c_{2}$ & $t_{2}$ & $\mathrm{n}_{2}$ \\
\hline$r$ & $a_{r}$ & $\mathrm{p}_{\mathrm{r}}$ & $b_{r}$ & $\mathrm{q}_{\mathrm{r}}$ & $c_{r}$ & $t_{r}$ & $\mathrm{n}_{\mathrm{r}}$ \\
\hline Total & A & $\mathrm{p}$ & B & $q$ & $\mathrm{C}$ & $t$ & $\mathbf{N}$ \\
\hline
\end{tabular}

possible to carry out a goodness of fit test on this table to test whether the data support the hypothesis that the lung is homogeneous with respect to the three components. If $p, q$, and $t$ are the overall estimates of the proportions of the 
three components, then, under the homogeneity hypothesis, the expected number of points in the components on slice I would be $p n_{1}, q n_{1}$, and $t n_{1}$ respectively. The $\chi^{2}$ test can thus be carried out as usual, finding $\frac{\text { (observed-expected) }}{\text { expected }}{ }^{2}$ for each cell of the table, and summing this over all the cells. Under the hypothesis of homogeneity, this sum will be distributed as $\chi^{2}$ with (number of components - 1) (number of slices-1) degrees of freedom, and the hypothesis can thus be tested. As the samples carried out in practice are systematic and not random samples, the observed number of points in each cell will be closer to the genuine expected number, since for this type of physical problem it is almost certain that a systematic sample is more precise than one that is random. Hence, under these conditions the homogeneity hypothesis will not be wrongly rejected because the sample is systematic.

Table III gives the result of this experiment. It will be seen that in each instance the value for $P$ is less than 0.001 , which indicates that there is a highly significant difference between the various slices. Although this difference is statistically
TABLE III

RESULTS OF THE HOMOGENEITY TEST IN ALL FIVE CASES USING GRID B

\begin{tabular}{c|c|c|c|c|c}
\hline $\begin{array}{c}\text { Case } \\
\text { No. }\end{array}$ & $\begin{array}{c}\text { No. of } \\
\text { Slices }\end{array}$ & $\begin{array}{c}\text { Degrees } \\
\text { of Free- } \\
\text { dom }\end{array}$ & $x^{2}$ & $\mathbf{P}$ & $\begin{array}{c}\text { Total No. } \\
\text { of Points } \\
\text { Counted }\end{array}$ \\
\hline I & 9 & 16 & 76.92 & 0.001 & 757 \\
\hline II & 13 & 24 & 130.6 & 0.001 & 1,630 \\
\hline III & 15 & 28 & 355.8 & 0.001 & 2,202 \\
\hline IV & 14 & 26 & 118.2 & 0.001 & 1,292 \\
\hline V & 12 & 22 & 94.62 & 0.001 & 1,983 \\
\hline
\end{tabular}

significant, the actual amount of the difference is also important. In fact the difference can be seen to be considerable. If, for instance, the values obtained for the percentage of emphysema in the individual slices of case I are compared, it will be seen from Table $I$ that the variation is large. Thus, in slice $I$, a value of $18 \cdot 1 \pm 2 \cdot 77 \%$ of emphysema was estimated, whereas in slice VIII it was $47 \cdot 4 \pm 2 \cdot 74 \%$; the value for the whole lung was $35 \cdot 2 \pm 0.85 \%$. It follows from these observations that the entire lung must be sampled if a reasonable degree of accuracy with, say, a final

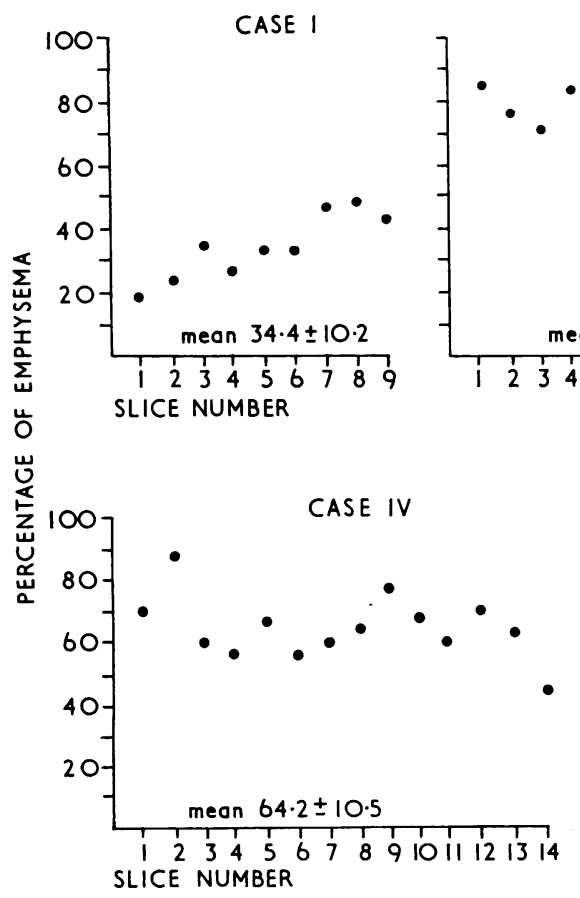

CASE II

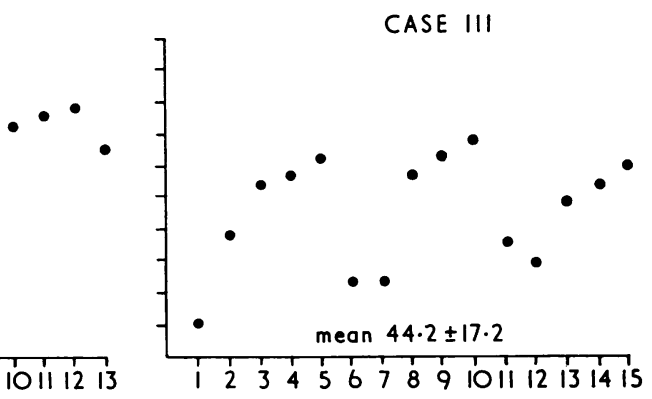

FIG. 2. Illustrates the percentage of emphysema found on each slice. There is a considerable variation in the quantity of emphysema throughout the lung. In each case the mean value for the percentage volume of emphysematous tissue is given for the entire lung, together with the standard deviation. 
percentage standard error of 5 to $10 \%$ is to be obtained. The difference between the amount of emphysema in each slice of lung, in each case, is illustrated graphically in Figure 2 . It can be seen that in all the cases the distribution of emphysema is not uniform in the lung nor does it follow any well-defined general law.

It is interesting to note that if the $\chi^{2}$ test is applied to the estimates given by grid $C$, the difference between slices is not significant. This is due to the fact that the total number of points counted was insufficient to give the required sensitivity to test the differences between slices. However, if it is decided that the estimates given by grid $C$ are acceptable in a particular case, this does not mean that it is sufficient to take only one slice. The necessity for whole-lung sampling has been demonstrated using the other grids and, as with them, the use of grid $C$ on a single slice will result in a biased estimate, i.e., an estimate of the proportions of the slice not of the whole lung.

The thickness of the slices is a matter of some importance. The closest approach to a uniform distribution of points throughout the lung is obtained if the slice thickness is the same as the distance between points on the grid. In practice, the slices are best kept to a thickness of $1 \mathrm{~cm}$. or slightly more, because it is a matter of some difficulty to cut uniform slices thinner than this. Furthermore, this is a very suitable thickness for histological blocks should these be required. In order to estimate the total number of points that will be counted in a lung with slices of approximately $1 \mathrm{~cm}$. thickness, using grid $B$, it is of value to know the ratio of the number of points counted to the volume of the fixed lung in these cases. The mean for this ratio was 0.65 to $0 \cdot 70$. The value is unlikely to be more precisely defined than this because of the technical difficulty of cutting uniformly thick whole-lung slices.

These results are of practical importance since they indicate that the distribution of emphysema throughout the lung is by no means uniform and that estimation of the quantity of emphysema from examination of a single slice, or whole-lung section, may give a totally erroneous impression of the amount of disease present in the entire lung. Recently, Duguid, Young, Cauna, and Lambert (1964) published their results on the estimation of the surface area of the lung in emphysema from observations made on the complete histological examination of one whole-lung slice. The results obtained in the present investigation, and those $\overline{\bar{c}}$. obtained in a previous series of experiments for $\overline{\mathrm{D}}$ sampling the lung for histological analysis (Dunnill, 1964), indicate that such single slice ${ }^{\infty}$ samples are not representative of the quantity of $\overrightarrow{0}$ disease present in the entire lung. Indeed, if $\overrightarrow{-}$ estimates of the quantity of some component are being obtained from an organ, unless it is known $\overrightarrow{\vec{*}}$ that this quantity is uniform throughout the ${ }^{x}$ organ, or varies according to a well-known, fully $O$ specified law, then it is not sufficient to base estimates on samples drawn from one part of the $\vec{N}$ organ; the entire organ must be sampled.

\section{SUMMARY}

The point-counting technique for estimating the volumes of normal and abnormal tissue in the lung is described and analysed with reference to five cases of emphysema.

The principles underlying the selection of a grid, and the total number of points to be counted in a lung in order to achieve a given standard error, are discussed. The larger the volume proportion to be estimated, the fewer is the number of points that need to be counted in order to obtain $\stackrel{\mathbb{D}}{\mathbb{2}}$ a given standard error.

It has been shown that it is necessary to sample the entire lung, by examining a series of slices of equal thickness, in order to obtain a reliable result. Thère is a highly significant difference between slices, showing that the distribution of emphysema in the lung is not homogeneous.

One of us (M.S. D.) is in receipt of a personal grant from the Medical Research Council. A grant $\delta$ for apparatus was given to aid this research by the Board of Governors of the United Oxford Hospitals.

\section{REFERENCES}

Delesse, A. (1847). Procédé mécanique pour déterminer la composition des roches. C.R. Acad. Sci. (Paris), $25,544$.

Duguid, J. B., Young, A., Cauna, D., and Lambert, M. W. (1964). The internal surface area of the lung in emphysema. $J$. Path. Bict., 88, 405.

Dunnill, M.S. (1962). Quantitative methods in the study of pulmonary

pathology. Thorax, 17, 320 . quantitative histological analysis. Ibid., 19, 443 .

Gough, J., and Wentworth. J. E. (1949). The use of thin sections of entire organs in morbid anatomical studies. J. roy. micr. Soc., $69,231$.

Weibel, E. R., and Vidone, R. A. (1961). Fixation of the lung by formalin steam in a controlled state of inflation. Amer. Rev. resp. Dis., 84, 856. 